\title{
Procyclical Effects of IFRS 9 - Illustrated by a Simulation on the Hungarian Banking System*
}

\author{
Gábor Szigel
}

The impact of the IFRS 9 accounting standard on amplifying procyclical bank behaviour has been hotly debated since the introduction of the standard. This paper contributes to the debate by a unique simulation, in which we estimated, what the losses and capital position of the Hungarian banking system would have been during the 2008-2013 crisis episode if at international level subsequently adopted IFRS 9 had already been in effect at that time. Our results show that IFRS 9 would have led to the recognition of losses, which would have been more concentrated in the beginning of this crisis episode, (but not early enough, in the pre-crisis period). As a result, the banking system's aggregated capital adequacy ratio would have been more than 20 per cent (2.7 percentage points) lower at the onset of the crisis (end of 2008) than it was in reality (9.1 per cent rather than 11.8 per cent). This could have forced bank owners to undertake capital increases sooner and in larger amounts or to push their banks towards even stronger deleveraging, i.e. towards more procyclical behaviour. Our results are in line with the findings in the literature that the introduction of IFRS 9 increases the procyclicality of banks' impairments in such a manner that it shifts the recognition of impairments towards beginning of crises (but not towards pre-crisis periods!). Although the procyclical effect of IFRS 9 demonstrated in our simulation is quite large, this is attributable to the special depth and complexity of the 2008 crisis episode in Hungary, which involved a sovereign crisis, a banking crisis and a credit crunch at the same time. Thus, our results suggest that the procyclical impact of IFRS 9 can be more easily managed under 'normal' recession circumstances.

Journal of Economic Literature (JEL) codes: E32, E61, G21, M41, M48

Keywords: IFRS 9, actual impairment, banking supervision, macroprudential policy, procyclicality

\footnotetext{
* The papers in this issue contain the views of the authors which are not necessarily the same as the official views of the Magyar Nemzeti Bank.

Gábor Szigel is a Senior Manager at Deloitte Hungary. Email: gszigel@deloittece.com

The views expressed in this study are those of the author only, and they should not be construed as those of Deloitte in any way.

The Hungarian manuscript was received on 16 December 2020.

DOI: http://doi.org/10.33893/FER.20.2.6090

${ }^{1}$ IFRS: International Financial Reporting Standards
} 


\section{Introduction}

How would the Hungarian banking system's accounting losses and capital adequacy have evolved if at international level subsequently adopted IFRS 9 accounting standard had been introduced before the 2008 crisis? Would Hungarian banks have behaved less or more procyclically? Would the probability of bank failures have been higher or lower?

These are interesting questions, as the literature usually attributes stronger procyclicality ${ }^{2}$ to banks after the introduction of IFRS 9, and the 2008-2013 crisis in Hungary was so severe that if IFRS 9 does indeed have a considerable effect in terms of strengthening procyclicality, it would have certainly been felt under such circumstances. Therefore, this paper presents a scenario analysis (simulation) estimating how impairments would have evolved in the Hungarian banking system in 2008-2013 if IFRS 9 had been introduced before the crisis, for example from 1 January 2007. In doing so, based on the rate of the actual incurred losses, we estimate how much impairment banks should have recognised using the expected credit loss (ECL) approach of IFRS 9, assuming that their models would have been able to accurately predict the actual losses incurred. ${ }^{3}$ In other words, the simulation uses a 'perfect foresight' assumption.

The paper is divided into the following sections. Chapter 2 provides an overview on why the IFRS 9 standard amplifies banks' procyclicality. Chapter 3 presents the relevant empirical findings in the literature. Chapter 4 briefly describes the relevant key features of the Hungarian banking system's crisis episodes in 20082013. Chapter 5 discusses the main assumptions of the simulation before the results are shown in Chapter 6 . Chapter 7 lists the imperfections in the simulation's assumptions and how they may distort the results. Finally, Chapter 8 summarises the main conclusions.

\section{The procyclical features of IFRS 9}

At their 2009 meeting, G20 leaders called on international accounting bodies to reform the IAS 39 accounting standard for banks' provisioning based on incurred loss introduced in 1984. Although the stated objective of the G20 was to reduce the procyclical behaviour of the banking system, there is a general consensus in the literature in that the IFRS 9 accounting standard introduced in lieu of IAS 39

\footnotetext{
${ }^{2}$ There is no universally accepted definition of the procyclicality of banks' behaviour. In this paper, the procyclicality of the banking system means that the behaviour of the banking system continues to heat the economy during an expansion in the business cycle, while it causes a deeper recession during contraction. The crucial underlying mechanism is that in a crisis, increasing credit losses reduce banks' available capital, which prompts them to curb lending. At the same time, they become even more risk-averse due to the losses incurred in the crisis, which leads to an even stronger credit crunch.

${ }^{3}$ For more, see Chapter 5 and 7.
} 
in 2018 increased the procyclicality of banks' impairment (see, for example: ESRB 2019; Huizinga - Laeven 2019; Plata Garcia et al. 2017).

The most important novelty in the IFRS 9 standard is the introduction of the ECL based estimation of impairment, even for the (performing) portfolio without objective evidence of impairment. Under IFRS 9, banks' financial assets that are measured at amortised costs (e.g. loans) are classified into the following three categories:

- Stage 1: assets without evidence of a significant increase in credit risk (SICR) since initial recognition. The impairment to be recognised for these equals the 12-month expected loss of these assets;

- Stage 2: assets with evidence (e.g. payments 30-90 days past due, rating downgrade, restructuring) of a SICR since initial recognition. For these assets, impairment equals the lifetime expected loss;

- Stage 3: assets with objective evidence of incurred losses (e.g. payments over 90 days past due, other unlikely-to-pay (UTP) events). This category basically comprises transactions with objective evidence for incurred losses, for which impairment had to be recognised even under the old IAS 39.

Nevertheless, IFRS 9 also requires banks to take into account forward-looking information (FLI) when estimating ECL-based impairment. As a result, banks need to estimate the point-in-time (PiT) value of expected losses for Stage 1 and Stage 2 assets, reflecting the current position of the business cycle. This PiT estimate differs from the long-term through-the-cycle (TTC) type of parameters used in the internal rating-based approach (IRB) approach of the Basel capital requirements. The fact that the requirement of IFRS 9 to consider FLI (enforcing the PiT correction) conflicts with the prudential approach during an expansion in the business cycle has already been pointed out by others (Borio 2018).

Accordingly, the effects of IFRS 9 that amplify procyclicality arise from the following:

- cyclical volatility in ECL impairment in all Stage 1 and in some Stage 2 assets: when the state of the economy deteriorates, the 12-month expected loss values in Stage 1 increase in particular, but - to a smaller extent - so does the Stage 2 lifetime expected loss, ${ }^{4}$

\footnotetext{
${ }^{4}$ In Stage 2, cyclical volatility is lower, since the PiT correction aligned with the position of the business cycle is typically performed by banks for only the first 1-2 years of the given loans' total maturity, since no reliable forecast on the economy's health is available for farther down the forecast horizon. Therefore, the farther points on the forecast horizon are usually calculated with the TTC parameters, without cyclical movements.
} 
- due to the deterioration in portfolio quality, some customers migrate from Stage 1 to Stage 2 (and of course to Stage 3), where higher provisioning keys are assigned to them: of course, migration to the non-performing (Stage 3) category was already present in IAS 39, as well, which also caused procyclicality. But the possibility of still-performing assets migrating to Stage 2 is a novelty in IFRS 9. Since for the same (still performing) loan, the 12-month ECL has to be recognised in Stage 1 and the lifetime ECL needs to be recognised in Stage 2, the Stage 2 impairment may be several times higher than in Stage 1, especially for long-term loans.

The change in the procyclicality in banks' impairment due to IFRS 9 is illustrated in Figure 1: it can be seen that the impairment of both Stage 1 and Stage 2 loans fluctuates with the business cycle. In fact, when a performing asset suffers SICR (significant increase of credit risk since the initial recognition) as a crisis unfolds, it must be classified as Stage 2, and an impairment based on lifetime ECL is assigned to it, instead of the 12-month ECL.

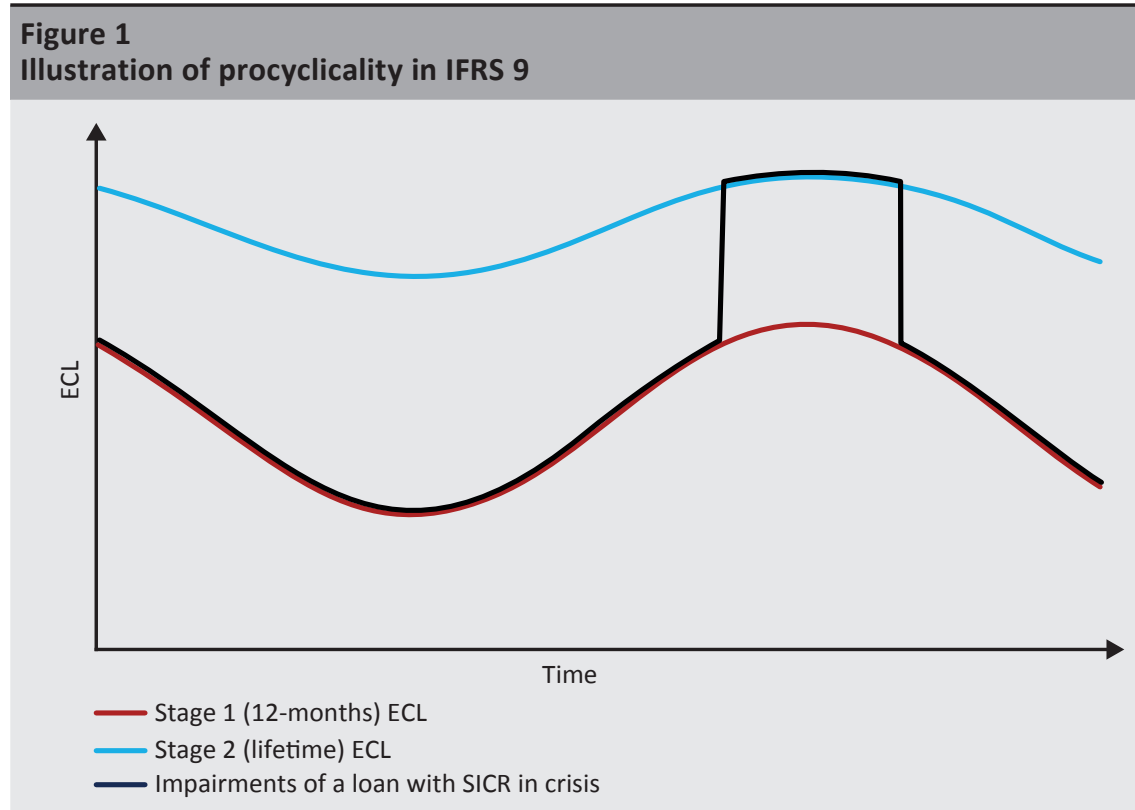

The fact that impairment exhibits a fluctuation does not in and of itself imply that this fluctuation is also procyclical, and indeed, the initial regulatory intention during the IFRS 9 introduction was to compel banks to recognise surplus impairment in 'good times'. However, this is not facilitated by the IFRS 9 framework, for various reasons: 
- In Stage 1, with the 12-month ECL, potential economic shocks beyond the 12-month period cannot be taken into account. In other words, even if a bank was certain that a deep recession was looming two years down the road, it would be unable to incorporate its effect into the 12-month ECL;

- Although the standard requires banks to calculate expected credit loss as a weighted average of several macroeconomic scenarios (at least two), and dynamically changing the weighting of the scenarios (increasing the probability of a crisis scenario in 'good times' and decreasing it in a crisis) provides some opportunity for countercyclical behaviour, this has a very limited impact. During an expansion, banks need to assign a low weight to the scenarios with a deep recession and thus a large increase in impairment, in line with the general expectations. Unlike the calculation of capital requirements, IFRS 9 does not allow impairment to be calculated along conservative estimates, since the financial statements based on it have to reflect a true and fair view rather than a prudential one;

- The criterion for classification into Stage 2 is a significant increase in credit risk, which in practice often means payments past due over 30-90 days or a deterioration in the debtor's internal rating. However, these events typically occur when a crisis unfolds, rather than in the 'good times' before that. ${ }^{5}$

The procyclical effects of IFRS 9 are mitigated in case of banks that use an IRB approach to calculate the capital requirements of their credit risks, because the increased impairment during a crisis reduces the so-called IRB shortfall ${ }^{6}$ at these institutions, which in turn improves own funds (see also Háda 2019). This can partly offset the profitability-reducing effect of increased impairment, which thus also reduces capital. Nonetheless, there is absolutely no such offsetting effect in the case of the banks using the Standard Approach (and the financial systems mostly consist of such banks).

Therefore, IFRS 9 has several elements that make it likely that the procyclicality of banks' impairment will eventually increase, even if unintentionally.

\footnotetext{
${ }^{5} \mathrm{~A}$ good example for this is that during the first months of the crisis related to the Covid-19 pandemic that unfolded from March 2020, banks' ratings of corporate credit portfolios improved, since the balance sheet ratings were based on the latest balance sheet data from 31 December 2019, and the impact of the crisis was often missing from the behaviour information known to banks.

${ }^{6}$ Pursuant to Article 159 of the European Capital Requirements Regulation, at banks using the IRB approach, the recognised impairment must cover the expected loss of the portfolio (expected loss $=$ PD*LGD). Otherwise, an IRB shortfall occurs, which must be deducted from own funds (CET1 capital). However, excess provisions can be added to own funds, more specifically Tier 2 capital.
} 


\section{Overview of the literature}

Not much time has passed since the introduction of IFRS 9 in 2018, therefore the empirical analyses that were first published mostly focused on the effects of the introduction itself. They usually showed that the transition to IFRS 9 slightly increased banks' impairments and reduced capital adequacy (for the Hungarian banking system, see: Háda 2019 and Csekei et al. 2018). This is not surprising, since the impairment to be recognised for performing portfolios (in Stage 1 and partly in Stage 2) was a new element in the standard, while the impairment of the Stage 3 portfolio remained practically the same as under IAS 39.

However, in itself the one-off change in the amount of impairment is irrelevant from the perspective of procyclicality, which is determined by the dynamic change in impairment levels across years, as this is reflected in banks' impairment and own funds. Moreover, the one-time capital-reducing effects of the IFRS 9 transition are probably negligible compared to an additional capital shock that could be expected in a potential stress scenario, as demonstrated by Plata Garcia et al. (2017) in a simulation for Spanish banks.

The procyclicality of IFRS 9 was proven by Abad and Suarez (2017) with a simulation model. Although this was a theoretical model, its parameters were calibrated to actual banking data from the euro area. The authors found that IFRS 9 considerably increases banks' profitability in good times, and significantly reduces their capital position in times of crisis (thereby substantially increasing the probability of recapitalisation). Nevertheless, the authors argued that even if these effects are substantial, they can be offset by macroprudential supervisors' well-calibrated countercyclical capital buffers.

Gaffney - McCann (2019) examined the procyclicality of the Stage 2 classification of portfolios for Ireland: using a sample of 100,000 Irish mortgages, they estimated the share that would have been classified as Stage 2 between 2008 and 2013 if IFRS 9 had already been in effect at that time. The authors used the transactions' arrears status (31-90 days in arrears) and restructuring status (forborne) and a significant increase between the loan's PD at origination and its current PD re-estimated by the authors as triggers for classification as Stage 2. According to their results, the share of Stage 2 debtors would have exhibited significant procyclicality: it would have increased from 5 to 50 per cent between 2008 and 2012, before falling to 30 per cent by 2015 (while the proportion of NPLs was never over 20 per cent in this period). It should be noted here that more than half of the authors' Stage 2 debtors were classified there based on the rise in their PD, which is a rather speculative classification criterion, where banks' practices may differ widely (in contrast to the 
other SICR criteria based on arrears for 31-90 days, which is straightforward and objective).

In another analysis, the ESRB (2019) compared the results of the ESRB's 2014, 2016 and 2018 Stress Tests. They concluded that in the 2018 stress test under the new IFRS 9 regime, the simulated losses of banks were more front-loaded to the first year of the hypothetical crisis, whereas in the 2014 and 2016 rounds (under the old IAS 39 regime), the incurred loss-based impairment was distributed much more evenly across the three crisis years.

Finally, an implicit acknowledgement of the excessive procyclicality of IFRS 9 can be seen in the fact that European supervisors and the EBA have issued several statements and recommendations starting from March 2020, in response to the Covid-19 crisis, urging banks to avoid practices leading to excessive procyclicality in impairment. Furthermore, the EBA published a recommendation on how banks should NOT consider debtors subject to a payment moratorium as restructured, which automatically classifies them as Stage 2. A useful overview of these measures can be found in Boel - Gringel (2020). On the other hand, the views of the same supervisors and the EBA shifted considerably towards the end of 2020: from December 2020 or even earlier, they urged credit institutions to recognise impairments reflecting the actual risks of the loan portfolios impaired by the Covid-19 crisis, instead of mitigating procyclical effects, (for example: EBA 2020; $E C B$ 2020). This may suggest that after the initial 'shock', procyclicality was not considered as a severe risk to financial stability as insufficient provisioning.

All in all, there is consensus in the literature that IFRS 9 increased procyclicality in banks' impairments, although the fact that this was significant or represented a threat to financial stability does not seem to be clearly proven (especially in view of supervisors' responses in 2020). Nevertheless, as far as the author is concerned, no similar simulation based on data from a real crisis and covering the loss and capital adequacy data from the entire banking system has been produced on this topic. (In fact, the Covid-19 crisis will still not be fully suitable for testing the procyclical effect of IFRS 9, as this crisis was 'too sudden', and, as things at the time of writing of the study stand, it was followed by a similarly swift recovery: by the time it was possible to incorporate the expectations of a fairly deep recession in 2020 into banks' models, the timeframe for forward-looking information had already shifted to the 'bounceback' forecast for 2021, which did not require as extensive a PiT correction of PDs as in a drawn-out recession.) 


\section{The situation of the Hungarian banking system in the 2008-2013 crisis episode}

The Hungarian banking system experienced a particularly deep crisis episode in 2008-2013, making this especially suitable for simulating the procyclical effects of IFRS 9. This study does not endeavour to provide a detailed summary of the post2008 crisis in the Hungarian banking system, and only the most crucial phenomena necessary for the understanding of the topic of the paper are highlighted here in brief:

- classic over-indebtedness crisis: Hungary went into the 2008 crisis as one of the most heavily indebted countries in the EU, with its net external debt standing just a notch below 50 per cent of GDP. This debt arose from two main sources: the over-indebtedness of the state and the excessive and ill-structured indebtedness of households via the banking system, mainly in FX (Swiss francs);

- sovereign debt crisis: accordingly, the drying-up of money markets in 2008 immediately caused a sovereign debt crisis, reflected in a surge of sovereign risk premiums, which forced Hungary to enter into a stand-by arrangement with the IMF to avoid state bankruptcy;

- 'hidden bank crisis': the proportion of banks' non-performing loans peaked over 20 per cent in the household sector and the corporate sector. Total credit losses, including the losses arising from the government's debtor rescue campaigns ${ }^{7}-$ amounted to close to 100 per cent (!) of the banking sector's own funds as at the end of 2008. Bank failures were avoided only because the owners, typically foreign parent banks, kept recapitalising the Hungarian credit institutions concerned at roughly the extent and pace of impairment recognition;

- FX loan crisis: the bulk of household loans were outstanding in a foreign currency, mainly Swiss francs, against debtors without currency hedging. Since the Hungarian forint depreciated against the Swiss franc by around 60 per cent between 2008 and 2012 and the interest on the loans did not decrease despite falling CHF-LIBOR due to banks' unilateral pricing policy, FX debtors experienced a shock of a similar extent in their payment instalments.

As a result, the Hungarian banking system was in a difficult position after 2008 (Figure 2): the impairment recognised based on the incurred credit losses jumped from 0.4-0.5 per cent of the balance sheet total before the crisis to around 1.52.5 per cent (a threefold or fivefold increase) between 2009 and 2014. At the same time, profitability declined as well: although in 2009 banks were still able to offset

\footnotetext{
${ }^{7}$ The 'preferential early repayment' at the turn of 2011 and 2012 and 'the holding of financial institutions to settlement and forint conversion' in 2014.
} 
their increased risk costs by unilaterally raising customer interest rates, the banking sector suffered losses for five years in a row between 2010 and 2014. It must also be borne in mind that the recognition of impairments on an incurred loss basis ultimately proved to be overly pessimistic in the case of Hungarian banks: in the years after 2014 the banking system was able to make reversals from the released impairment on the recovering NPLs for years, increasing their net income. In this sense, the main criticism levelled against the incurred loss-based recognition of impairment, namely that the recognition of losses is thus 'too little, too late', was not true (at least as regards the 'too little' part), and in fact in this respect the old accounting standard also proved to be overly procyclical in hindsight.

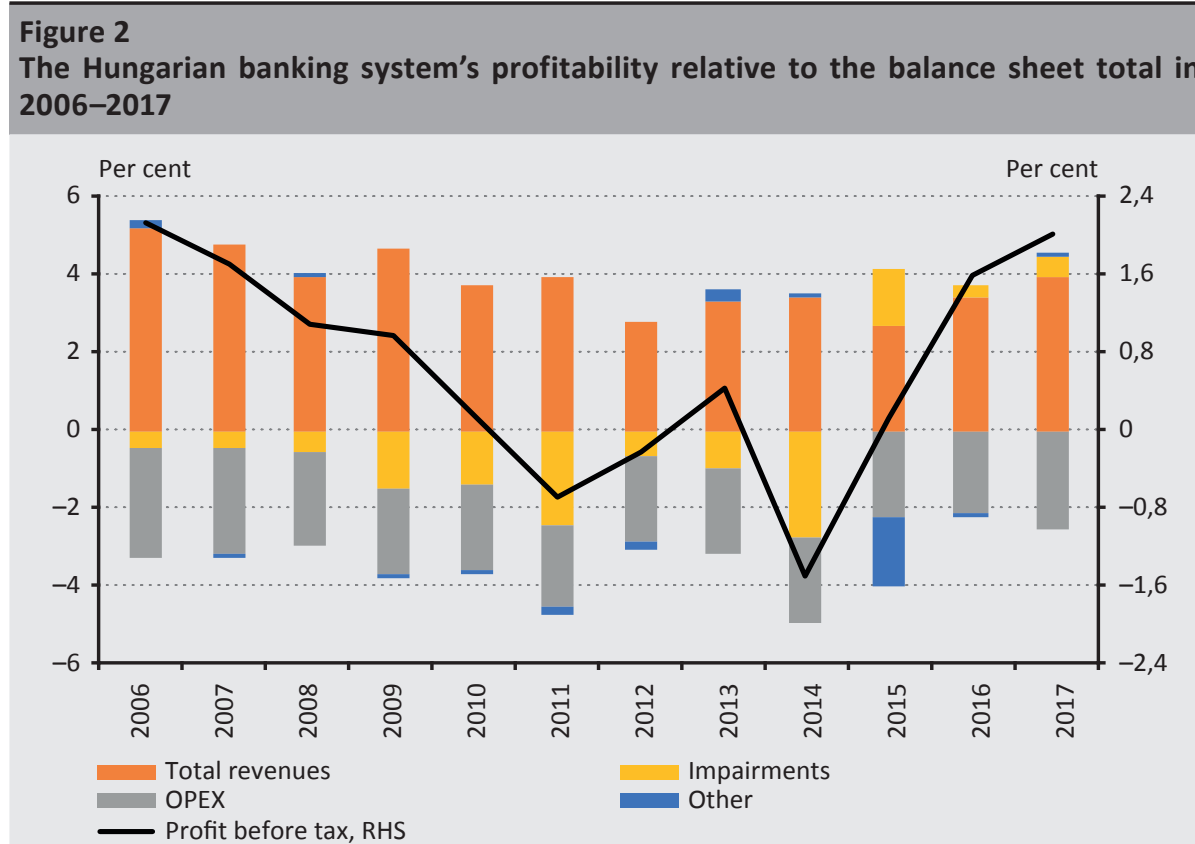

Source: Calculations based on the time series of the data from the sectors supervised by the MNB

Consistent with the above, the banking system's capital adequacy position also came under pressure (Figure 3): although the capital adequacy ratio almost doubled from 11.8 per cent at the end of 2008 to 19.9 per cent at the end of 2015 , this was mainly due to capital injections from the owners (with an effect of +10 percentage points between 2008 and 2015). Moreover, the banks also engaged in considerable deleveraging, and the capital adequacy-improving effect of this amounted to half of the impact of capital increases (around +6 percentage points until 2015). Without the capital injections by the owners, the banking system's capital adequacy ratio would have been below 10 per cent at the end of 2015. It also 
has to be underlined that the system-wide figure conceals the heterogeneity among banks: while certain banks proved to be more resilient, others performed below the banking system average. It is still certain that several large banks would have been unable to keep their capital levels above the minimum requirement without capital injections from the parent bank, possibly not even at the price of even more radical deleveraging.

\section{Figure 3 \\ The Hungarian banking system's capital adequacy ratio, and the decomposition of the change in the ratio relative to 2008}

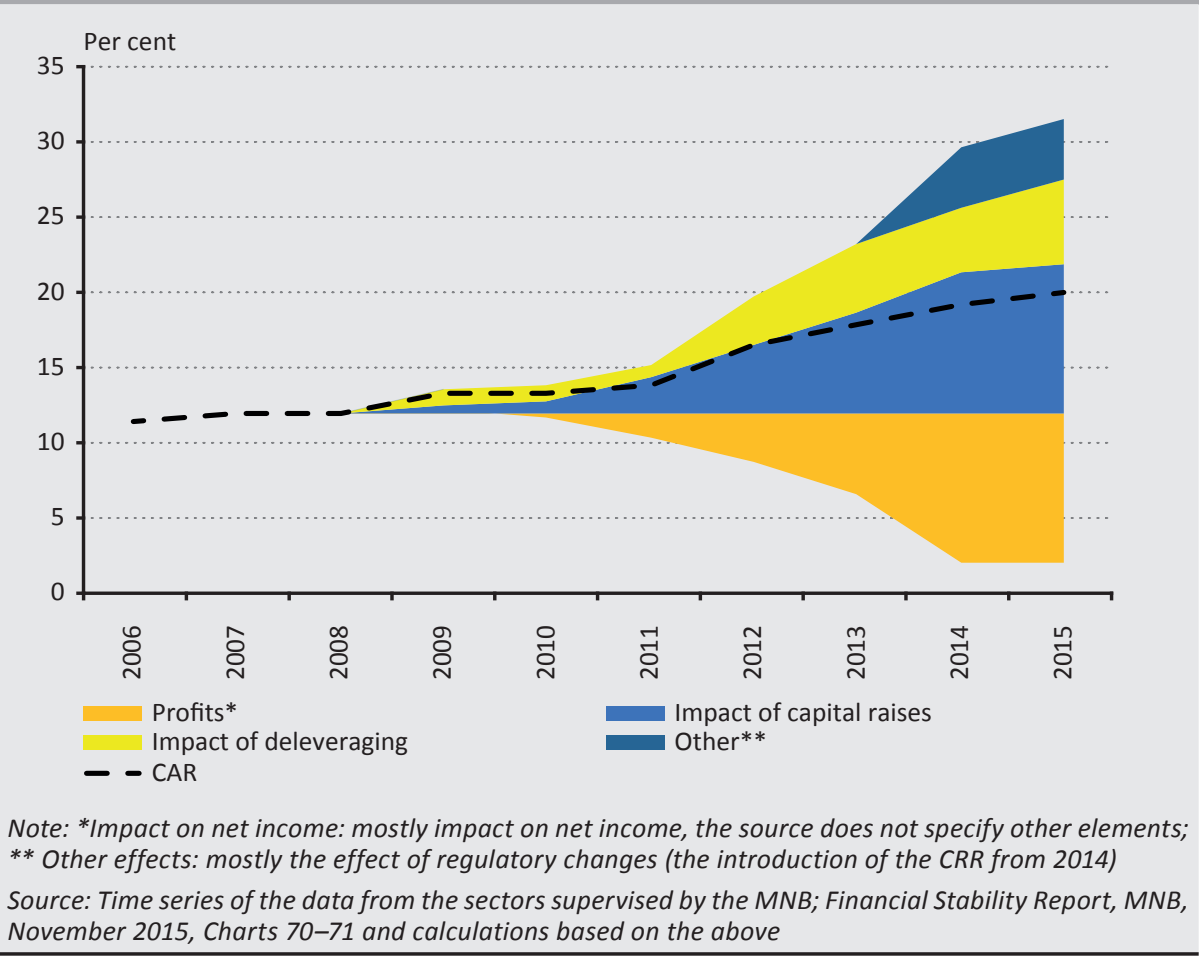

Overall, the Hungarian banking system thus experienced a significant deterioration in portfolio quality and a related loss of capital in the crisis episode that started in 2008, which not only prompted it to rein in lending activities in a procyclical manner, but would have also led to several bank failures in the absence of capital injections from parent banks. In other words, this was a very deep crisis, which is suitable for illustrating the procyclical effects of IFRS 9 precisely because it highlights cyclical fluctuations. 


\section{Simulation}

In the simulation, the potential additional procyclicality arising from an imagined introduction of IFRS 9 prior to the 2008 crisis is quantified relative to the Hungarian accounting standards (HAS) in effect at that time. ${ }^{8}$ HAS was selected as a basis of the comparison, because the available financial reporting of the Hungarian banking system was made by HAS (which was very similar to IAS 39).

First, a more detailed summary of the HAS-based regulations in effect at that time is necessary. According to HAS, bank assets had to be classified into the categories presented in Table 1 based on expected losses (Balás 2009), and the impairment to be recognised was the expected credit loss. Nevertheless, in practice banks often classified assets into categories based on the number of days in default, especially in the household segment, using the following ranges: problem-free (overdue by 0 or 1-30 days), to be watched (overdue by 31-60 days), substandard (overdue by 61-90 days), doubtful (overdue by 91-365 days), bad (overdue by over 1 year). (In addition, especially in the mortgage credit segment affected by FX lending, certain banks classified the transactions with an increased loan-to-value ratio due to exchange rate changes into the 'to be watched' category, even if this was not standard practice.)

\section{Table 1}

Expected loss ranges for the different rating categories based on the Hungarian accounting standards in effect in 2009

\begin{tabular}{c|c} 
Category & Expected loss \\
\hline Problem-free & $0 \%$ \\
\hline To be watched & $1-10 \%$ \\
\hline Substandard & $11-30 \%$ \\
\hline Doubtful & $31-70 \%$ \\
\hline Bad & $71-100 \%$ \\
\hline
\end{tabular}

Source: Balás 2009, p. 3.

Although at first glance the HAS approach is also based on ECL, it actually differs significantly from IFRS 9 in several respects:

- no provisioning for problem-free transactions: under HAS, impairment for expected credit loss only had to be recognised for transactions with objective evidence of probable losses that may not be fully recovered from the collateral. ${ }^{9}$

\footnotetext{
${ }^{8}$ These were stipulated in the version of Government Decree No. 250/2000 in effect back then.

${ }^{9} \mathrm{HAS}$ also allowed collateral to be taken into account: for example in extreme cases, even a long-overdue item (clearly classified as Stage 3 under IFRS 9) could be classified as problem-free if it had collateral of exceptional quality and sufficient quantity (e.g. cash collateral in custody of the lender). By contrast, under IFRS 9 such a transaction would be Stage 3 with low LGD. Of course, this example was not frequent or realistic.
} 
By contrast, under IFRS 9, for Stage 1 transactions impairment must be recognised without objective evidence of a probable loss (in other words for problem-free loans);

- no increase in the customer's credit risk since origination is taken into account: in HAS, only the current ECL counts, taking into consideration not only the probability of default (PD), but also loss given default (LGD). For example a customer experiencing a major rating downgrade can remain problem-free if there is no objective evidence of probable losses (e.g. no late payments);

- the adjustment based on forward-looking information only affects the nonproblem-free portfolio: since in HAS zero impairment has to be recognised for the problem-free portfolio elements, which would be mostly classified as Stage 1 and to a lesser extent as Stage 2 under IFRS 9, its cyclical adjustment is not applicable.

The above disparities are more or less in line with the most important differences between IFRS 9 and IAS 39.

At the same time, the approach of HAS and IFRS 9 to non-problem-free portfolio elements according to HAS (which therefore fall into the 'to be watched' category or below) is not that different: basically, both standards require impairment to be recognised for the transactions overdue by over 30 days, ${ }^{10}$ and it more or less equals the lifetime ECL in both cases. Although HAS did not explicitly require forwardlooking information to be taken into account, its ECL-based approach actually included assumptions on the economic environment, even if they were not very significant, since expected credit loss was already recognised for the whole lifetime of the loan.

Accordingly, beyond the not very frequent exceptions, the basic differences between HAS and IFRS 9 would have been due to the fact that the problem-free portfolio is assigned a 0-per cent impairment under HAS:

- some of the problem-free portfolio would have been assigned impairment different from zero as Stage 1 under IFRS 9 (12-month ECL),

- and some of the problem-free portfolio would have been classified as Stage 2, with impairment recognised accordingly (based on lifetime ECL).

\footnotetext{
${ }^{10}$ There may be exceptions: IFRS 9 allows banks not to classify transactions overdue by over 30 days as Stage 2 with proper justification, and under HAS such transactions can remain in the problem-free category with strong collateral, but these are just the exceptions.
} 
In the present simulation, these two effects are quantified retrospectively in the three dimensions below: ${ }^{11}$

1) Quantification of the impairment on the problem-free customer loan portfolio, separately for the portfolios potentially classified as Stage 1 and Stage 2,

2) The impairment dynamics of the potential classification of sovereign and interbank exposures as Stage 2,

3) The impairment dynamics of the classification of the performing FX loan portfolio as Stage 2.

The effects for the entire banking system are estimated separately for the three factors above, using the available data. The differences in the situation of individual banks cannot be taken into account due to the simulation methodology and lack of available data.

\subsection{Assumptions for the problem-free customer loan portfolio (without the FX loan effect)}

Stage 1 problem-free portfolio

Some of the problem-free debtors under HAS in the customer loan portfolio ${ }^{12}$ would have remained in Stage 1 under IFRS 9. For these exposures, banks would have had to recognise impairments amounting to the 12-month ECL. To estimate this, banks' actual annual incurred loss relative to total credit as per HAS is established as follows:

- the numerator of the loss ratio is the annual net impairment recognised in the banking system's consolidated profit and loss account. Although this indicator could theoretically include losses from other portfolio types, in reality almost 100 per cent of Hungarian banks' losses were incurred on the customer loan portfolio, and therefore this approach is correct,

- the denominator of the loss ratio is the annual average gross total of customer credit in the banking system.

${ }^{11}$ The effects arising from the three dimensions are cumulative on each other in the order presented here, because it reflects the probability with which these effects would have contributed to the provisioning policies strengthening procyclicality (from the most likely to the least likely).

12 The customer loan portfolio includes households and non-financial corporations. Debtors classified as financial corporations are discussed in the next subchapter. 
In the simulation, it is assumed that the impairment of the Stage 1 portfolio, the 12-month ECL, equals in all years the loss rate (loss / total loan volume) actually recognised by banks under HAS in the following year. In other words, it is assumed that the impairment under HAS measured incurred losses accurately, and that with 'perfect foresight' banks would have been able to predict the losses for the following year based on this. Thanks to this assumption, it is not necessary to make speculative assumptions on banks' scenario planning, while the dynamics brought by the forward-looking PiT correction of IFRS 9 into provisioning can be still illustrated. (This is useful because the exercise does not seek to run a simple 'what if' scenario, but also to establish the procyclical dynamics of IFRS 9.) Nevertheless, two one-off items resulting from two government interventions are excluded from the loss rate used for the simulation: the one-off bank losses recognised due to the early repayment scheme at preferential exchange rates in 2011 and the losses related to the Settlement Act of $2014^{13}$, as these cannot be assumed to have been foreseen by any bank's impairment model.

It is important to note that the perfect foresight for the loss path is only assumed from 2008, so the crisis unfolding at the end of 2008 takes banks by surprise in the simulation. This is a realistic assumption, since this is what actually happened, ${ }^{14}$ (just as the crisis caused by the Covid-19 pandemic completely took market participants by surprise). One of the procyclical effects of IFRS 9 arises precisely from this: risk parameters deteriorate rapidly during unexpected crises due to the suddenly pessimistic forward-looking information.

For the years where the banking system's impairment recognised as per HAS increased net income (a release occurred), a 12-month ECL of 0.5 per cent, roughly equalling the average loss ratio before the 2008 crisis, was assumed.

The annual loss rate estimated in this manner (the forward-looking 12-month ECL) can be seen in Figure 4. It clearly shows that in the simulation the IFRS 9 12-month $\mathrm{ECL}$ jumps at the end of 2008, as the effect of the unexpected crisis is incorporated into the forward-looking (PiT) adjustment of the ECL, and then it is smoothed back to the 'normal' value after the last crisis year of 2013.

\footnotetext{
${ }^{13} 2014$. évi LXXVII. törvény az egyes fogyasztói kölcsönszerződések devizanemének módosulásával és a kamatszabályokkal kapcsolatos kérdések rendezéséről (Act 2014 LXXVII on the settlement of questions concerning changes in the currency of certain consumer credit agreements and interest rate rules): https:// net.jogtar.hu/jogszabaly?docid=a1400077.tv

${ }^{14}$ For example the mean of the GDP forecast by the Magyar Nemzeti Bank for 2009 declined by over 10 percentage points between the publication of the August and December issues of the 2008 Inflation Report. A similarly dramatic decline was seen in the expectations of every other player.
} 

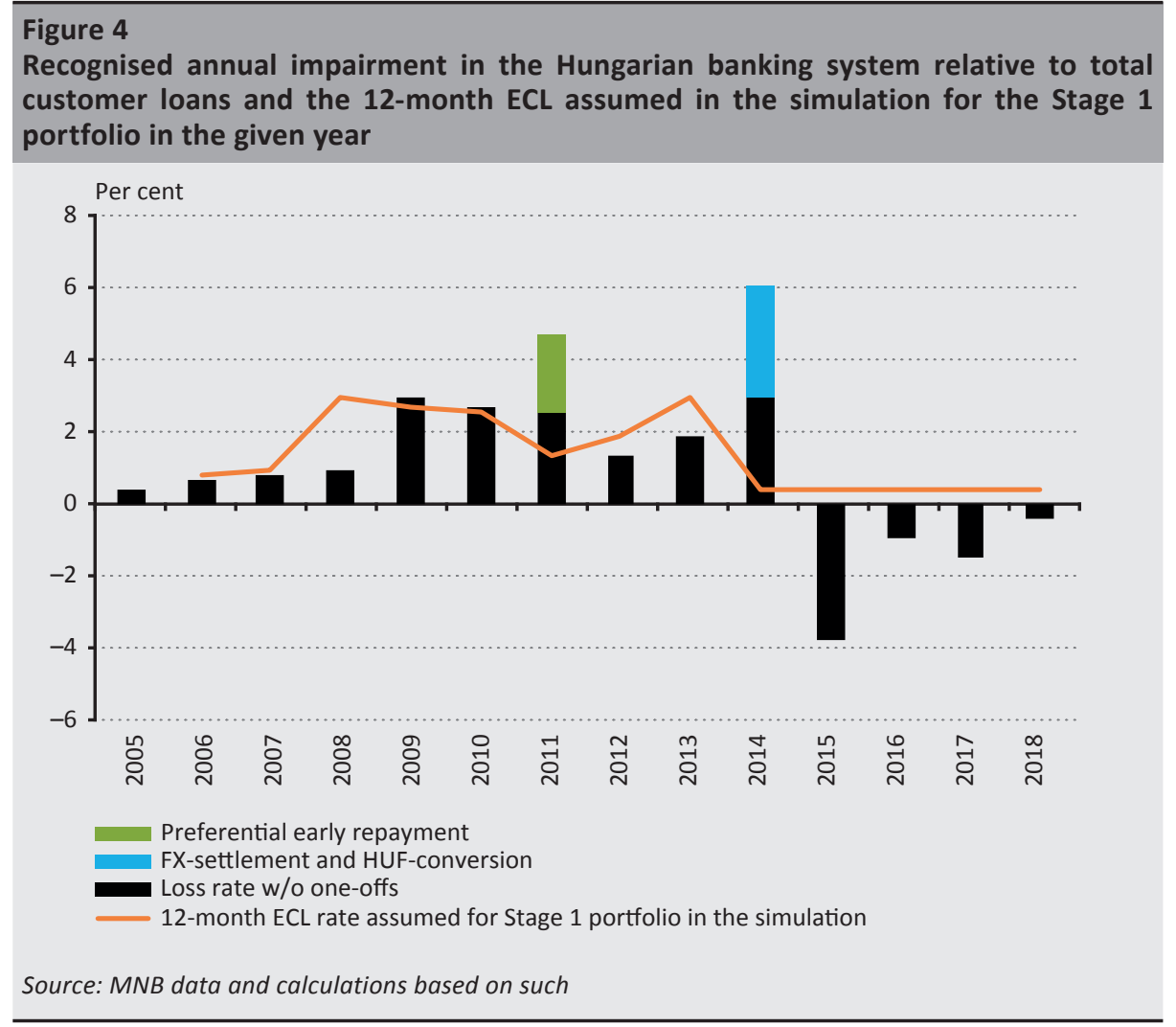

For all years, the impairment in banks' income statements equals the annual change in impairment volume assumed for the Stage 1 portfolio as described above. In other words, it is affected not only by the Stage 1 ECL but also by the change in volumes. The volume of problem-free Stage 1 loans is estimated by deducting the estimate of the problem-free Stage 2 loans from total problem-free loans, as described in the next subchapter.

\section{Stage 2 problem-free portfolio}

Determining the portion of the portfolio deemed problem-free under HAS to be classified as Stage 2 is more challenging. Customers who were restructured or in default for 30-90 days during the crisis were mostly classified by banks in the 'to be watched' category or below in HAS as well, and ECL-based impairment was recognised for them. Therefore, the recognition of losses related to them would probably have not been much different under IFRS 9. On the other hand, the portion of the portfolio recorded as problem-free under HAS without objective default but with a significant increase in credit risk relative to the date of borrowing would have been classified into Stage 2 under IFRS 9. However, there are no backward- 
looking data on this. (The reclassifications related to FX lending are discussed in Subchapter 5.3 rather than here.)

Therefore, we estimate the size of the problem-free Stage 2 portfolio by relying on a benchmark and utilising the calculations by Gaffney and McCann cited in the summary of the literature. They estimated that the share of the Irish mortgage loan portfolio to be classified as Stage 2 due to a rating downgrade was roughly 1.4 times the number of loans that were restructured or in arrears by 30-90 days (Gaffney-McCann 2019, Figure 4). Since the situation of the Irish banking system after 2008 was very similar to that of Hungary in 2008-2013, this proportion is considered a good benchmark. ${ }^{15}$ However, statistics containing restructured transactions in Hungary are not available for the crucial years of 2008-2009, and therefore the volumes of loans classified in the 'to be watched' and 'substandard' categories under HAS were used as a substitute for this indicator. This is rational since banks were mostly required to classify the restructured transactions in the 'to be watched' category or below, and the transactions past due by 30-90 days were roughly covered in the 'to be watched' and 'substandard' categories, ${ }^{16}$ so overall there is a substantial overlap between this indicator and the categories of Gaffney - McCann. (Nevertheless, the final results of the whole simulation are actually not that sensitive to this parameter (Figure 7).)

The 'problem-free Stage 2' ratio of the Hungarian customer loan portfolio calculated with the above assumptions is shown in Figure 5. If the portfolio classified as Stage 2 due to the rating downgrade as calculated above is added to the 'to be watched' and 'substandard' portfolios under HAS (which are presumably also Stage 2), it can be seen that the proportion of the Hungarian Stage 2 portfolio under IFRS 9 would have peaked slightly below 45 per cent during the 2008 crisis episode. This more or less tallies with the 50 per cent value estimated by Gaffney - McCann (2019) for the Irish mortgage portfolios.

\footnotetext{
${ }^{15}$ In both banking systems, the share of non-performing loans peaked around 20 per cent.

${ }^{16}$ Of course, this coverage is not perfect, since as noted above, under HAS the availability of collateral could considerably improve or reduce the rating.
} 


\section{Figure 5 \\ Proportion of the 'problem-free Stage 2' and other portfolio quality indicators}

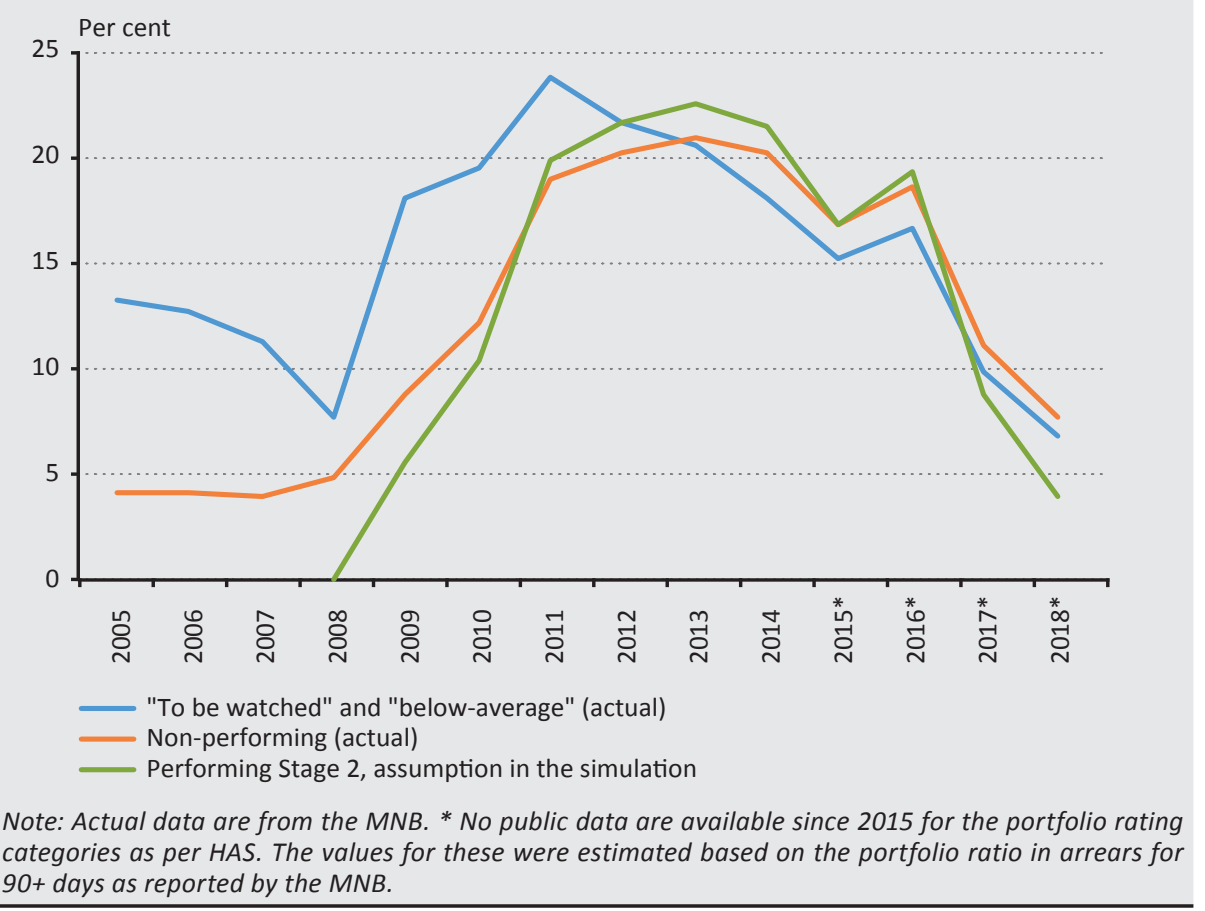

The lifetime ECL of Stage 2 loans is quantified as follows:

- we assumed the 'perfect foresight' already used for Stage 1 transactions. Thus, for all loans outstanding at the end of the $t$ th, we apply the loss rates as per HAS between $t+1 t+5$ years. The latter parameters were chosen because the average residual maturity of the customer loan portfolio of banks was somewhat over 4 years in this period,

- the forward-looking ECL was discounted by the discount factors in line with the current interest rate environment, ${ }^{17}$

- from 2014, when banks' HAS impairments started to increase net income due to releases, Stage $2 \mathrm{ECL}$ is calculated by interpolation between the value estimated for 2013 (the last year in the crisis) and the actual data for average ECL ratios according to IFRS 9 in 2018 (the year when IFRS 9 was introduced).

\footnotetext{
${ }^{17}$ The discount factor was calculated by estimating the average customer interest rate (effective interest rate). This was done by dividing the banking system's annual gross interest income by the portfolio of performing interest-bearing assets. The discount rate was calculated for the interest rates derived in this manner for the first four years.
} 
The Stage 2 lifetime ECL values thus determined (and the Stage $1 \mathrm{ECL}$ ) are shown in Figure 6. It can also be seen there that the relative fluctuation of the Stage $2 \mathrm{ECL}$ falls short of Stage 1, in line with the discussion in Chapter 2.

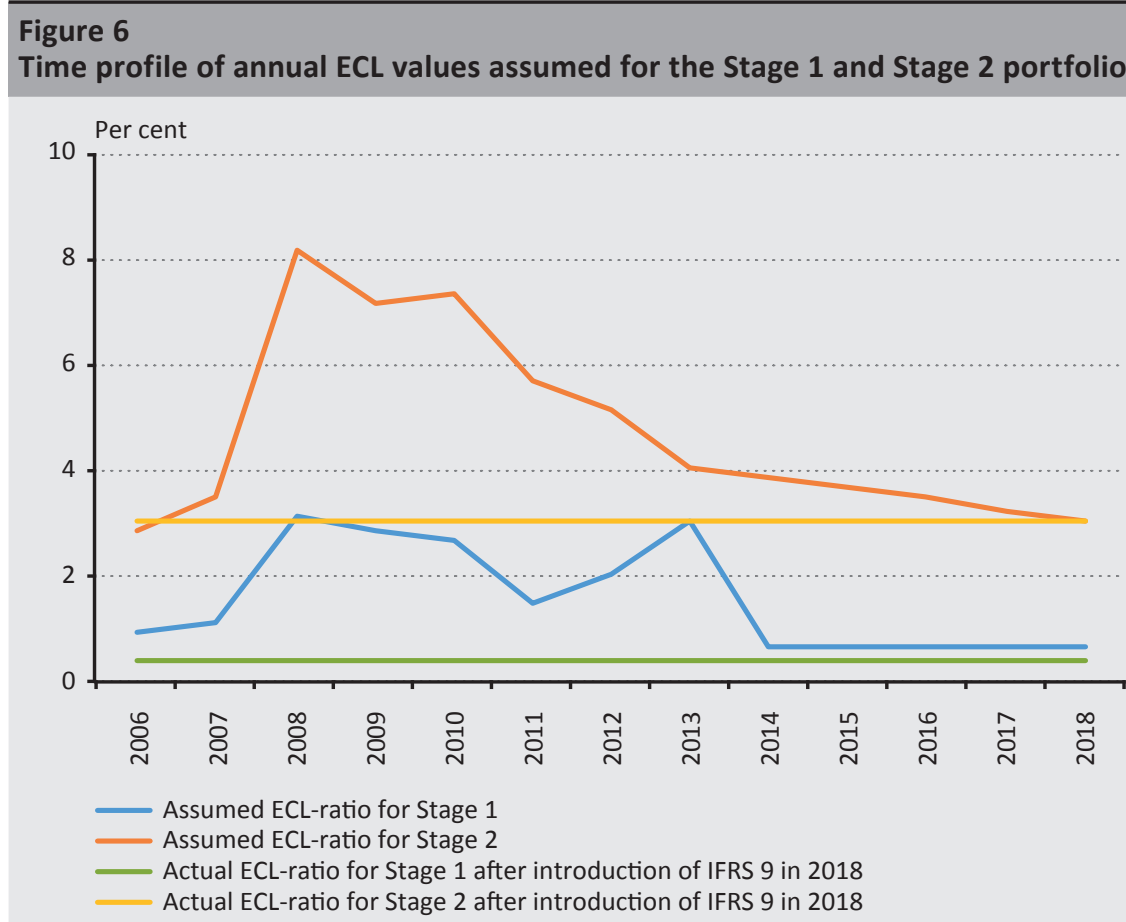

Note: Assumed ECL ratios are based on the author's calculations. Source of the actual data presented here: Háda (2019) Figure 6

The impairment in banks' income statements is calculated with the annual change in the assumed impairment volume for this portfolio segment as well.

Total effect on the problem-free portfolio (Stage $1+$ Stage 2)

Based on the above assumptions, the application of IFRS 9 to the problem-free portfolio at the end of 2008 would have required significant additional impairments as compared to HAS, while in the later crisis years additional releases would have been possible (Figure 7). All in all, during the period between 2008 and 2017, practically spanning an entire business cycle, impairment would have been the same under IFRS 9 as with HAS, because by the end of the period the ECL of the problem-free portfolio returned to the non-crisis state, where it had been before 2008. Figure 7 also shows that additional impairment under IFRS 9 would have been influenced more by the ECL related to the portfolio remaining in the problem-free Stage 1 category, in other words: by the effect arising from the forward-looking 
adjustment of risk parameters. This would have required provisioning of over 1 per cent of the banking system's balance sheet total in 2008 (HUF 320 billion). Compared to this, the migration of some of the problem-free portfolio into Stage 2 would have had a smaller effect, despite the substantial migration ratio (mostly because this migration would have taken place more gradually over the crisis years).

Between 2009 and 2011, when the net income-reducing impact of the problem-free Stage 2 portfolio is larger, the effect of the additional impairment of this portfolio segment exerted on the Gaffney-McCann parameter used for the size of the problem-free Stage 2 portfolio is more or less linear: by doubling the factor of 1.4 applied, which would entail the peaking of the Stage 2 transactions not in arrears at roughly 50 per cent of the total portfolio, the net income-reducing effect would be also almost doubled.

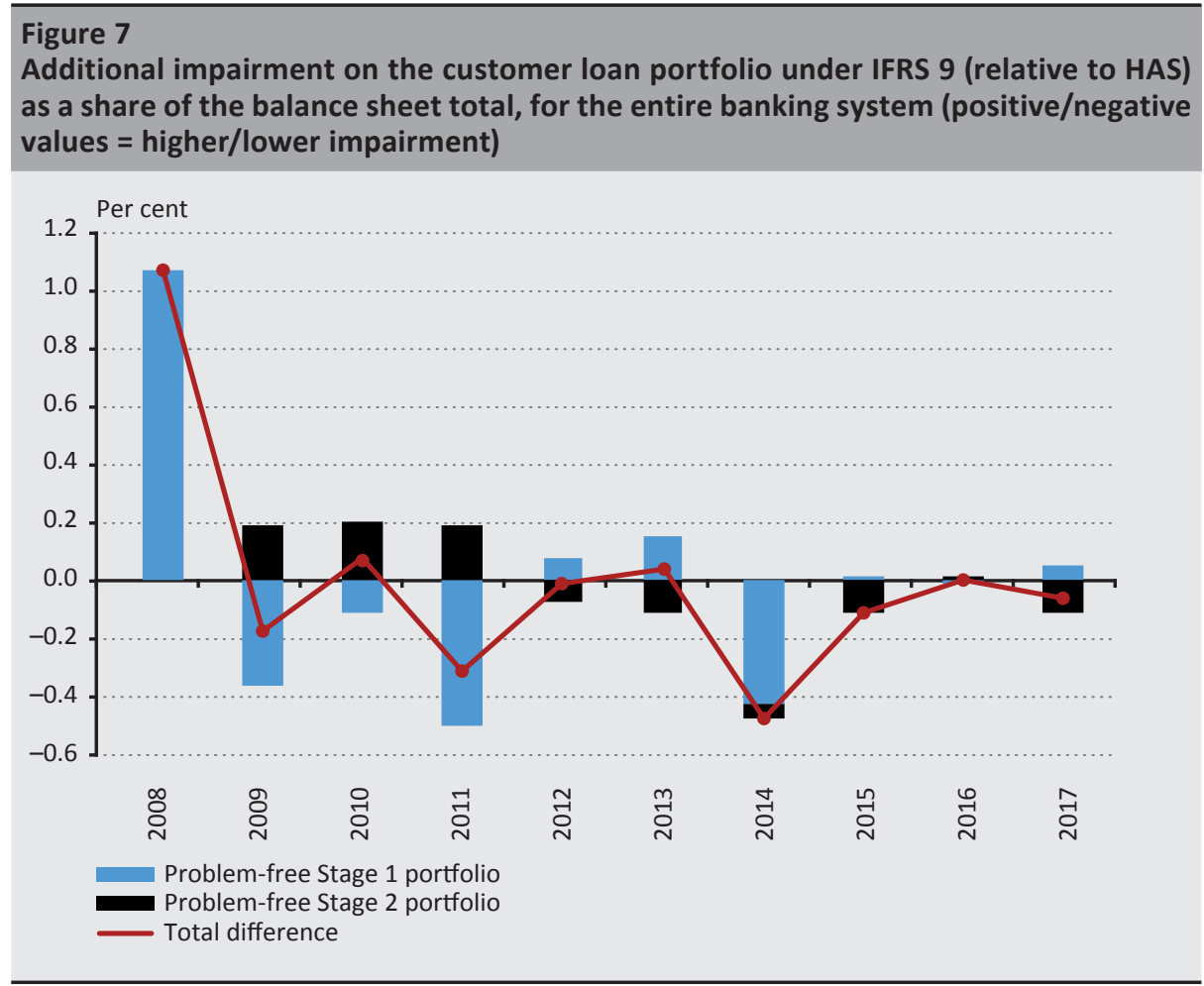

\subsection{Assumptions for sovereign and bank exposures}

If IFRS 9 had been introduced prior to 2008, the forward-looking PiT correction would have been applicable to the risk parameters of sovereign and bank exposures, and the classification of exposures as Stage 2 should also have been considered. The latter is true despite the fact that credit institutions usually apply the IFRS 9 
exemption for the so-called low default portfolios in the case of sovereign and sometimes also bank exposures. In other words, these exposures do not have to be classified as Stage 2 even if their risk has significantly increased since recognition, if remaining still low in absolute terms.

Nonetheless, the financial crisis that began in Hungary in 2008 was coupled with a sovereign debt crisis, which caused the government's risk premiums, such as its CDS spread, to spike (Figure 8) from close to zero before 2008 to 600-700 basis points. Hungary was repeatedly downgraded by credit rating agencies from 2008, and the country fell out of the investment category in 2011. Hungarian banks' risk premiums and their credit ratings, of the few institutions that had these at all, deteriorated in parallel with the sovereign rating.

In the face of such significantly and objectively increasing credit risk, it would have been difficult to argue against the necessity to classify exposures vis-à-vis the Hungarian sovereign and perhaps even Hungarian banks as Stage 2 under IFRS 9. Therefore, our simulation also includes an estimation for this scenario.

In this, it is assumed that banks would have classified their Hungarian government bonds (in the banking book) as Stage 2 at the end of 2008 (as the surge in CDS spreads and the recourse to the IMF package occurred in late 2008), and they would have kept them there until the end of 2014. The government bonds in Stage 2 are assumed to receive the average 5-year CDS spread for the given year as lifetime ECL. ${ }^{18}$ The basis for government bonds in Stage 1 is the 12 -month ECL, which we assume to be equal to the average 1-year CDS spread as calculated from the 5 -year CDS spread.

We have simulated the above impacts only for the sovereign portfolio, but no Stage 2 classification effect was quantified for bank exposures. This has several reasons: first, since most Hungarian banks had no readily measurable risk price indicators, a significant increase in credit risk would have been more difficult to establish here. Second, in the part of the banking sector owned by non-residents, the increase in credit risk could have been mitigated by the probability of support from the parent bank. Third, these bank exposures were also partly collateralised (with a low LGD). Furthermore, the amount of interbank loans in the Hungarian banking system was not really high (amounting to less than 5 per cent of banks' balance sheet total in 2008), and thus excluding this effect does not influence the overall picture.

\footnotetext{
${ }^{18}$ This is an acceptable benchmark as it is certain that the residual maturity of the government securities issued by the Hungarian state was around 3.5 years in early 2009 (Bíró - Horváth 2020), however, this includes the short-term treasury bills held by households, but excludes the typically longer-term bonds denominated in FX.
} 


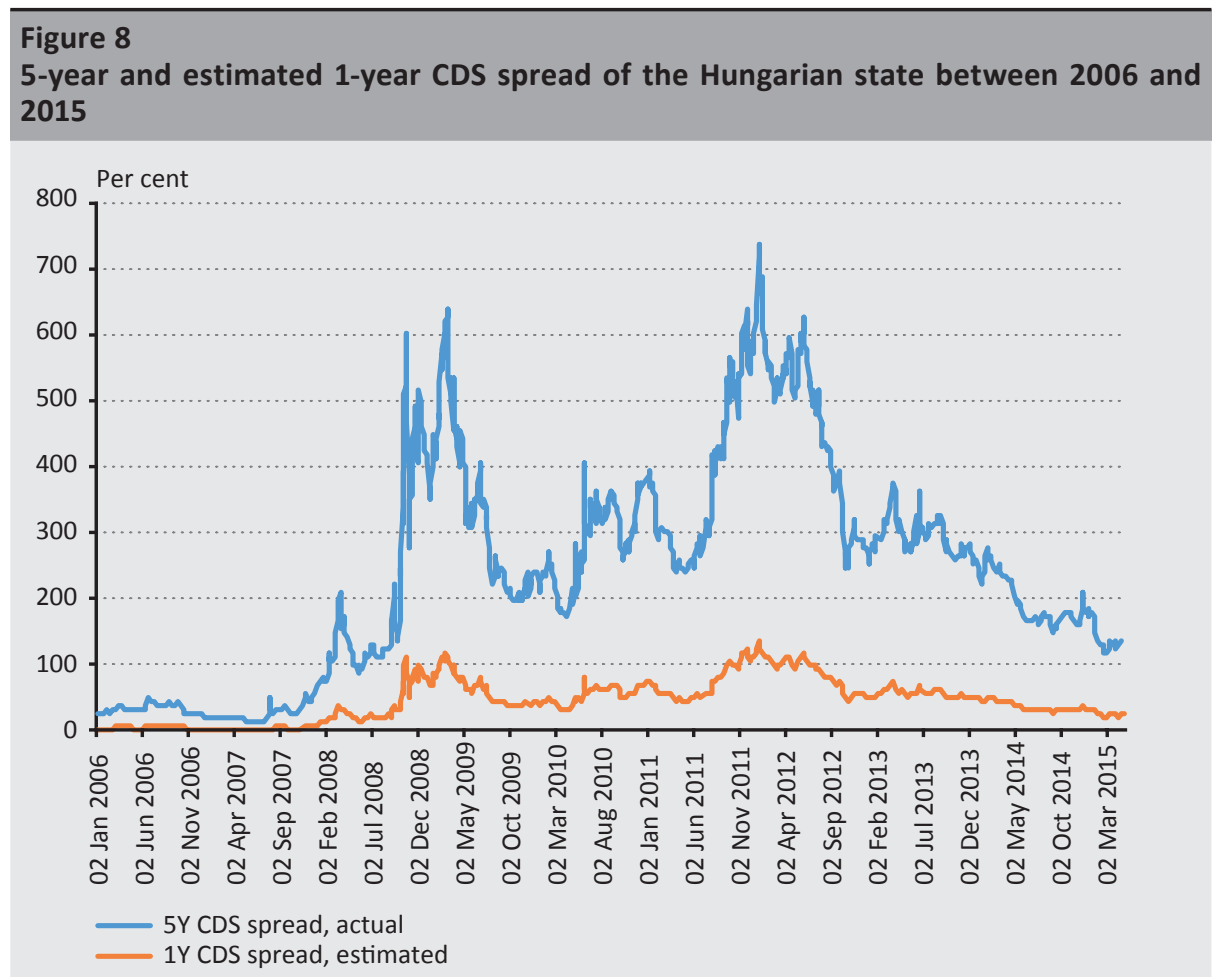

Note: The data on the 5-year CDS spread are from the MNB's Financial Stability Report, May 2015, Chart 13. The 1-year spread is the author's estimate.

Of course, classifying the sovereign portfolio as Stage 2 in the simulation is a speculative decision, and it can be assumed that banks and the supervisory authority would have been eager to avoid this in the given situation. They could have found numerous arguments for this: first, the CDS spread shows the credit risk of government exposures denominated in FX, which is much greater by nature than the government debt denominated in the domestic currency (and Hungarian banks mostly held government securities denominated in forint). In addition, the loan arrangement signed with the IMF in 2008 also considerably reduced the default risk of the sovereign (although in Greece private investors also incurred losses in the end, despite the IMF-EC-ECB rescue package). However, when the stipulations in IFRS 9 are taken literally, the default risk of the Hungarian sovereign undoubtedly increased significantly in 2008 (along with other sovereigns in the EU), so this scenario was realistic.

The impairment in banks' income statements is calculated with the annual change in the assumed impairment volume for the sovereign portfolio segment as well.

Based on the above, the simulated additional impairments under IFRS 9 relative to HAS would mainly have been significant in 2008, the year when Hungarian government bonds would have been classified to Stage 2 and the rising CDS 
spreads would have been first effective (Figure 9). After this, impairment would have reflected the dynamics of CDS spreads. Actually, since the price of Hungarian government securities was basically determined by the risk premium in this period, the introduction of IFRS 9 together with the significant increase in the chance for a state bankruptcy would have put the assessment of the banking book government bond portfolio on a quasi-mark-to-market basis.

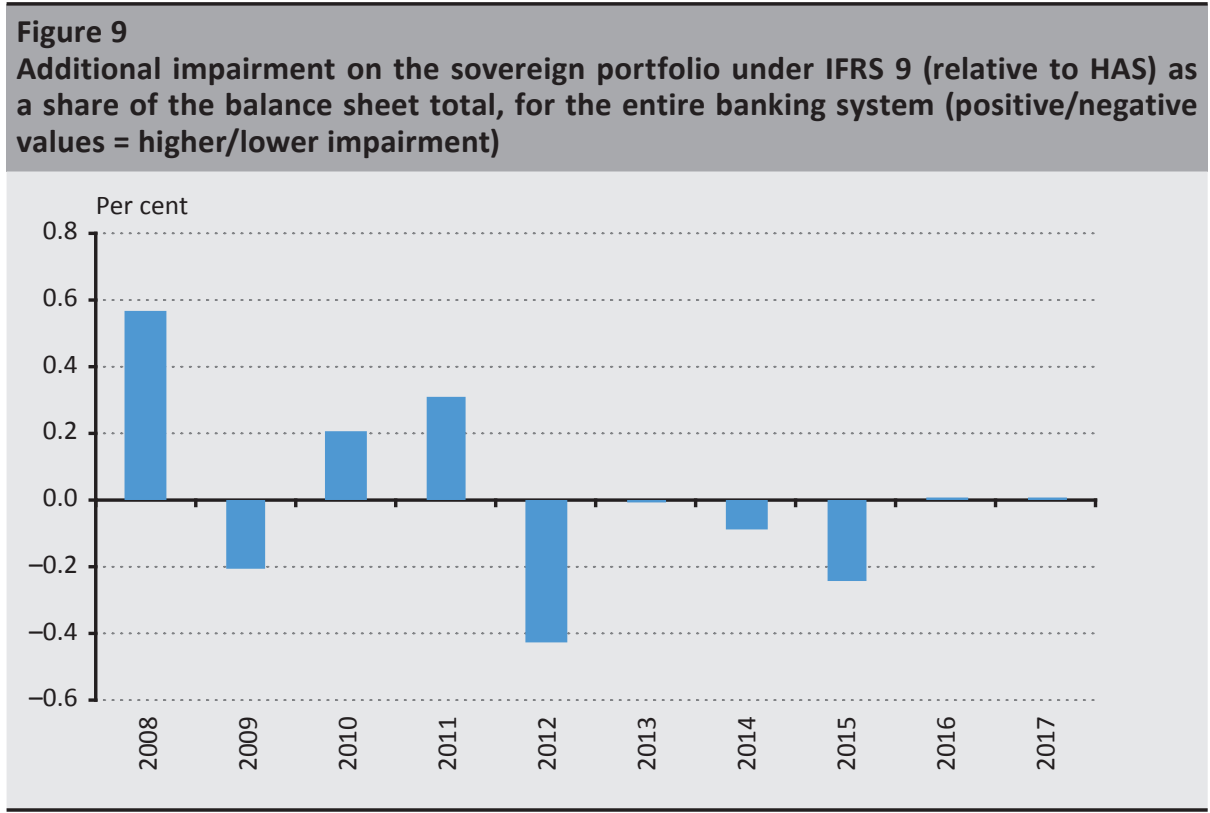

\subsection{Assumptions for the problem-free FX loans}

During the 2008-2013 Hungarian crisis episode, one of the most important sources of the financial system's vulnerability was undoubtedly the household debt in FX, which was mostly denominated in Swiss francs. Since retail FX debtors had no natural currency hedge (FX income), the depreciation of the forint, mainly against the Swiss franc, that started after 2008 had a substantial negative impact on their financial position. As Figure 10 shows, the forint had already lost almost 20 per cent of its value against the Swiss franc by late 2008 relative to 2007, and the depreciation was over 60 per cent by 2011. In most cases, the repayment instalments of Swiss franc debtors increased even more, because banks failed to pass on, through customers' lending rates, the reduction on Swiss franc interest rates that occurred at that time, and instead of that, banks made unilateral interest increases.

Although the IFRS 9 standard has no rules related specifically to FX loans, a major exchange rate shock affecting the borrower is difficult to interpret in any way other than a significant increase in credit risk since recognition, in other words an event 
triggering Stage 2 classification under IFRS 9. Although in such a situation banks would have definitely tried to separate the borrowers with an appropriately low payment-to-income ratio that prevented a substantial impact of the exchange rate shock on their financial position, due to the massive size of the shock and the loose lending conditions that prevailed prior to 2008, there would probably have been only a handful of such cases. Therefore, the simulation used a conservative approach and estimated a scenario in which banks would have been forced to reclassify all problem-free household FX loans as Stage 2. It is assumed that this would have occurred at the end of 2009 , since the forint exchange rate had already depreciated by 30 per cent during the year relative to the pre-2008 figure, when the majority of the Swiss franc loans were originated.

The same assumed Stage $2 \mathrm{ECL}$ is used for quantifying the relevant impairment effects as presented in Subchapter 5.1. Although the Stage $2 \mathrm{ECL}$ calculated there also contains corporate portfolio data, the distortion arising from this does not substantially influence the overall picture, as the NPL ratios and loss ratios developed similarly in the household and the corporate portfolios. Regardless of the FX effect, the classification as Stage 2 is not duplicated for the loans that had already been classified as Stage 2 due to the rating downgrade, as shown in Subchapter 5.1, and so no additional impairment is recognised for these due to the Stage 2 classification on account of their being denominated in a foreign currency, because they were already Stage 2 due to the rating downgrade (and, of course, the same goes for non-problem-free FX loans).

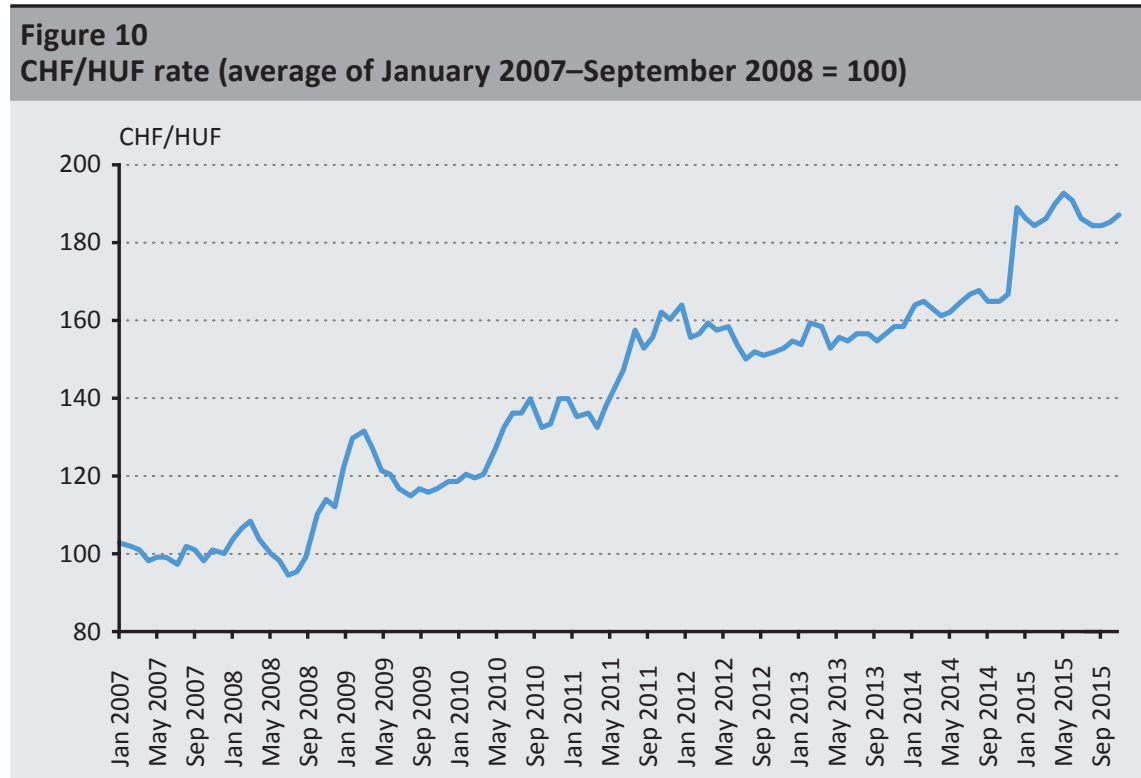

Source: $M N B$ 
The impairment in banks' income statements is calculated with the annual change in the assumed impairment volume for the reclassified problem-free FX loans as well.

Accordingly, the simulation shows that the additional Stage 2 classification of the household FX loan portfolio, affecting the portion not already classified as Stage 2 due to the rating downgrade and other indicators, would have mainly caused a major one-off loss to Hungarian banks in 2009 (Figure 11), the year when the reclassification would have occurred. After this, the impairment of this portfolio segment would have been determined by the PiT corrections based on forwardlooking information as applied to lifetime ECL (as shown in Subchapter 5.1).

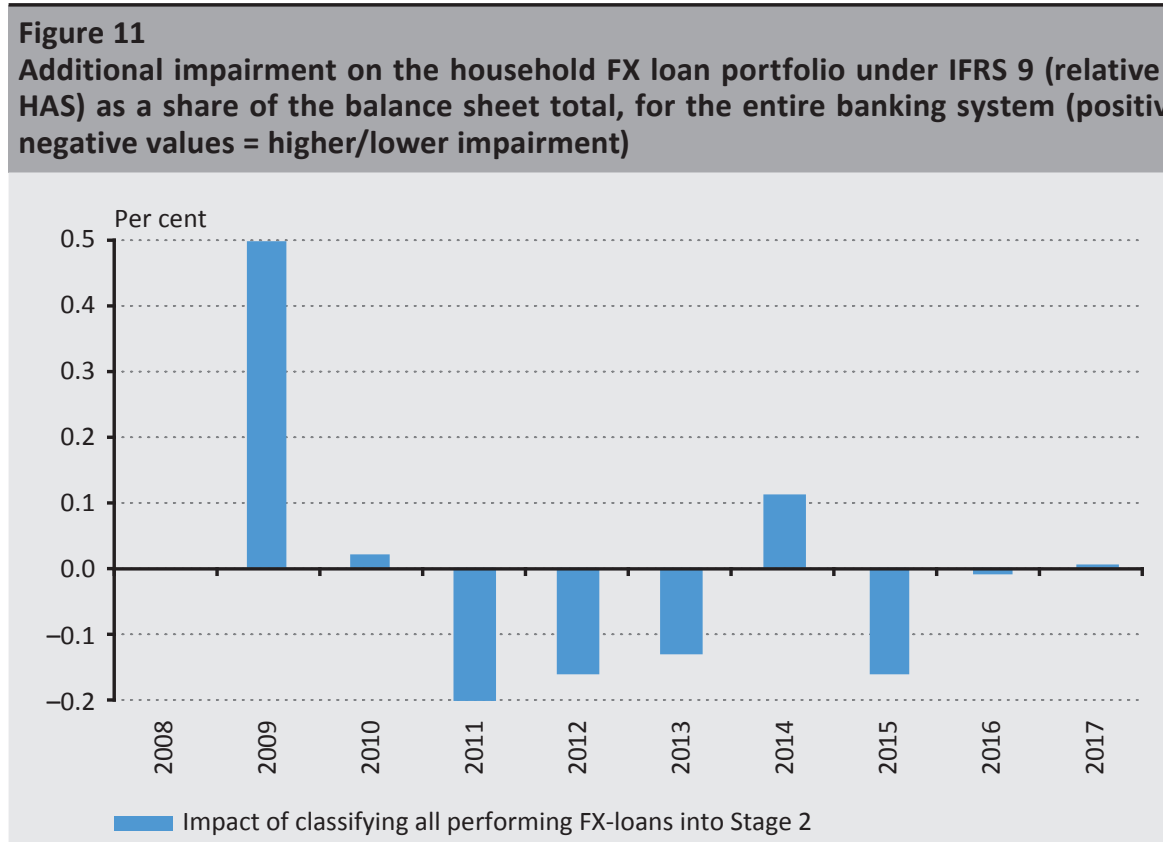

\section{Results of the simulation}

The results of the simulation are presented by layering the above three effects upon each other, as their partial effect on annual impairments has already been illustrated on separate figures above. When calculating the combined impact, first only the effect of the impairments for the Stage 1 and Stage 2 problem-free loans is estimated (because this is the least country- and position-specific, it simply results from the logic of IFRS 9). After this, the effects of the reclassification of the sovereign portfolio as Stage 2 are quantified, and then the classification of the FX loan portfolio as Stage 2 is added to that. 
The results of the simulation corroborate the findings in the literature: if IFRS 9 had been introduced in Hungary prior to the 2008-2013 crisis episode, the banking system's losses and recapitalisation needs would have been more front-loaded, materialising mostly during the onset of the crisis in 2008-2009. The more factors are taken into account, the more pronounced this effect is.

In themselves, the PiT-corrected Stage 1 impairment for problem-free customer loans and reclassification of some of the problem-free customers as Stage 2 exert the greatest impact: this would have been enough to reduce the strong pre-tax profits of the banking sector in 2008 to zero (Figure 13). In exchange, banks' losses would have been smaller in 2011-2014. It is important to see that the introduction of IFRS 9 would not have affected the amount of banks' actual total credit losses over the whole economic cycle, only the distribution over time of the recognition and reversal (!) of the losses.

If the IFRS 9 effects simulated for the problem-free customer loans is supplemented with the classification of sovereign exposures to Stage 2, the losses to be booked in 2008 would have been even more dramatic (Figure 12), making 2008, the eve of the crisis, the year with the greatest losses during the entire crisis episode. Added to this, the reclassification of all the problem-free FX loans as Stage 2 would have resulted in only a minor increase in losses, mostly in 2009 , which would have been followed by steadily diminishing reversals distributed over the following years.

\section{Figure 12}

Annual impairment recognised by the banking sector in the simulated scenarios

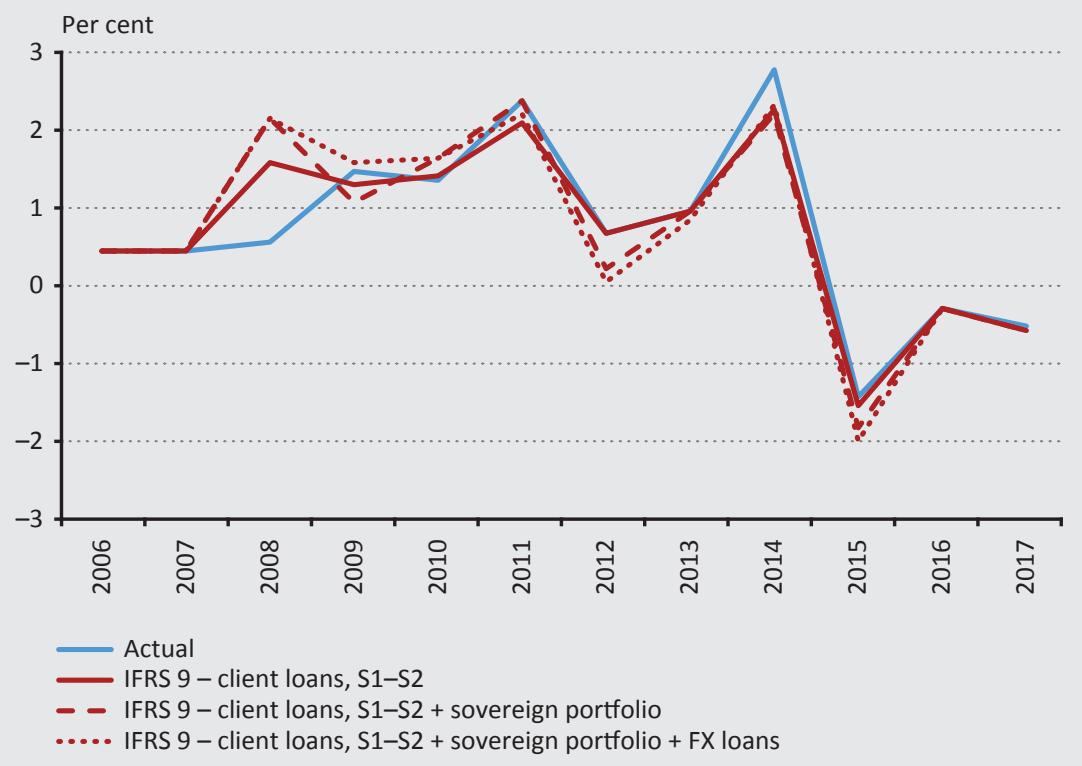


It should be noted that when the effects of all three simulated factors are taken into account, the application of IFRS 9 would have completely transformed the dynamics of the banking system's profitability. In reality (under HAS), after a final strong year in 2008, banks' profits declined practically continuously until 2014, but if IFRS 9 had already been applied, they would probably have experienced improving profitability following a huge loss in 2008. It cannot be ruled out that this latter scenario, i.e. the quicker recognition of losses, would have had a more positive effect on banks' willingness to lend.

\section{Figure 13}

The banking sector's pre-tax profits in the simulated scenarios

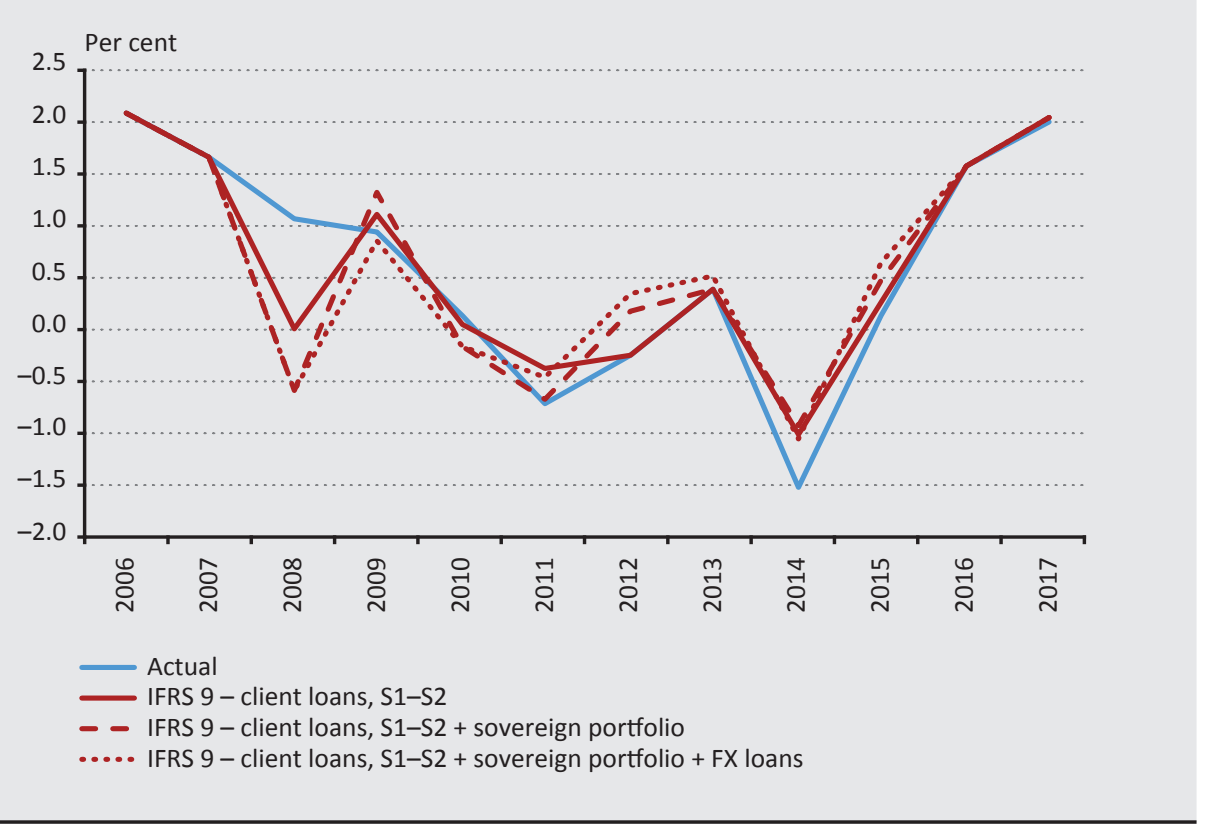

On the other hand, the introduction of IFRS 9 would have placed the banking system's capital adequacy under great pressure much sooner: the simulation shows that, ceteris paribus, the sector-wide 11.8-per cent capital adequacy ratio in 2008 would have diminished by 23 per cent ( 2.7 percentage points) to 9.1 per cent (Figure 14) if IFRS 9 had applied. If banks' owners had wished to maintain the same capital adequacy level until 2011 as in reality under HAS, they would have had to implement a capital increase amounting to 2.5-3.0 per cent of the banking system's risk-weighted assets (RWA) in 2008. This would have amounted to HUF 600 billion, roughly a quarter of the actual own funds of the banking system in 2008 or about 2 per cent of Hungary's GDP back then, in other words it would have been a massive amount. In the absence of this, banks would have been required to make stronger deleveraging efforts. 


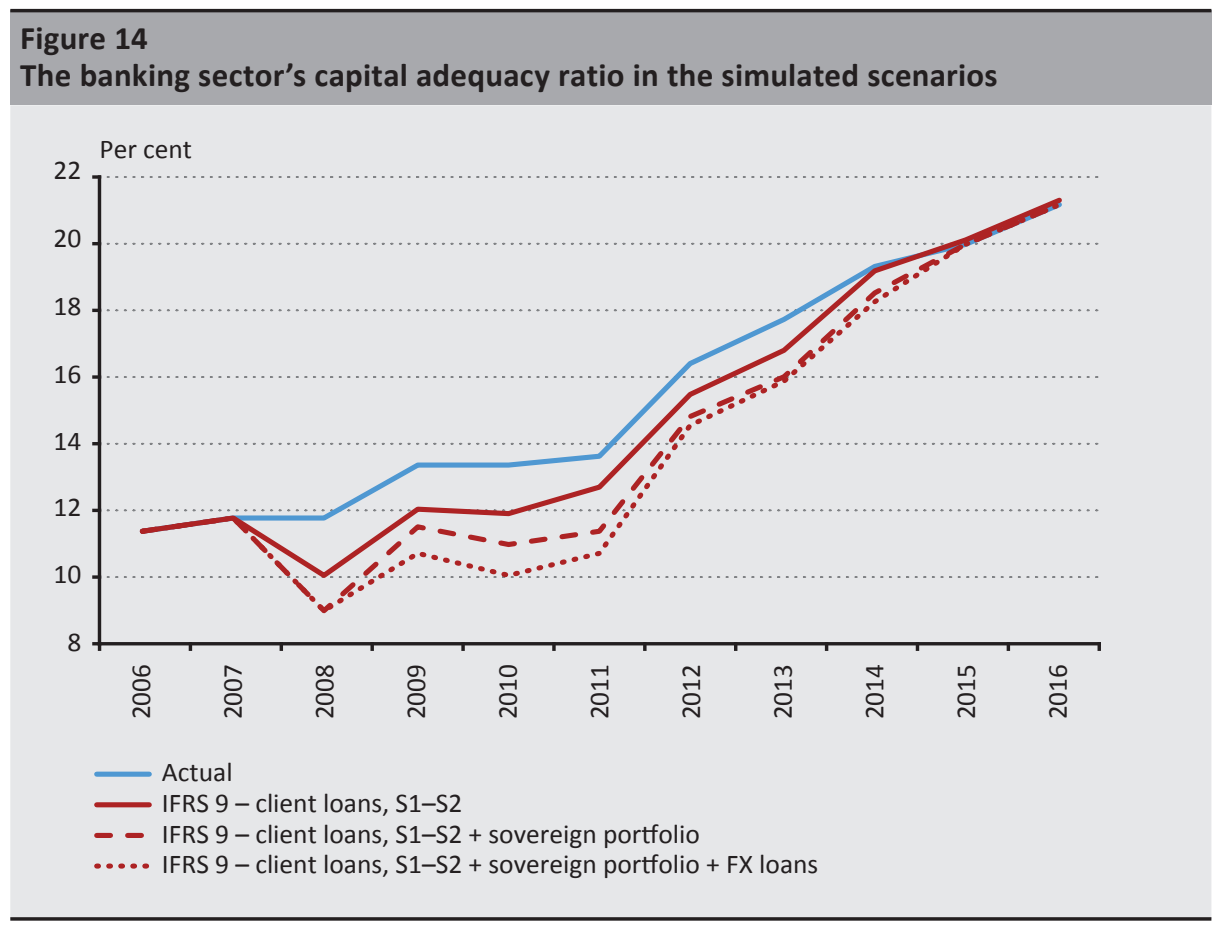

All in all, the owners of the banks in need of a capital injection would have had much less time to prepare for the losses and arrange the capital increases. This would have entailed the risk that Hungarian banks respond to the emerging situation by even more deleveraging, which, by definition, would have been even more procyclical behaviour. Had IFRS 9 been introduced, the banking groups in the region would have been faced with a similar (though maybe less severe) situation in several countries at the same time, and in extreme cases this would have jeopardised certain regional banking groups' ability or willingness to recapitalise their subsidiaries.

Admittedly, however, macroprudential supervision has come a long way since 2008, and almost at the same time when IFRS 9 was introduced, countercyclical elements appeared in regulation that were not available to supervisors in 2008 , such as the countercyclical capital buffer and the capital conservation buffer. In this context, the 2.7-percentage point decrease in the capital adequacy ratio simulated for the IFRS 9 introduction in 2008 does not seem that bad. Most of it could have been offset by an adequately calibrated countercyclical capital buffer (if the buffer would have been at its maximum of 2.5 per cent on the eve of the crisis, and then it would have been immediately reduced to zero by supervisors). In other words, macroprudential supervisors would have been able to offset the procyclical effects of IFRS 9, although this would have also meant that the buffer could no longer be used to encourage actual countercyclical bank behaviour, only to neutralise the immediate capital effects of the new accounting standard. 


\section{Assumptions influencing the results}

There are several factors that make it likely that in reality the procyclical effects of IFRS 9 would have been more muted than presented here:

- More optimistic expectations instead of perfect foresight: since the deterioration in banks' portfolio quality was a gradual, protracted process after 2008 (the volume of NPLs only peaked in 2012-2013), the expectations would only have caught up with the worsening situation later. This is all the more likely as the deterioration of certain economic indicators, especially the CHF/HUF rate, which is key from the perspective of FX loans, reached numerous historic highs, and most analysts did not expect this. It is therefore not unrealistic to assume that in reality banks would have calculated the forward-looking ECL of Stage 1 and Stage 2 portfolios with more optimistic parameters than what actually occurred, especially because they would have been interested in doing so. And due to the lack of earlier experience from crises of such magnitude, it would have been difficult to quantify the development of actual credit risk.

- Supervisory interventions: just as in present Covid-19 crisis, regulatory bodies would have had strong incentives at their disposal to prevent the use of loss estimates for accounting purposes that would have endangered financial stability. In this manner, they would probably have been able to prevent the classification of the entire FX loan portfolio and sovereign exposures as Stage 2, even if this had run counter to the spirit and expectations of the IFRS 9 standard.

All in all, it can be assumed that the authorities and market participants would have tried to make use of the large leeway in the estimation of ECL due to IFRS 9 to mitigate procyclical effects.

\section{Conclusions}

This analysis examined how much stronger procyclical effects would have been exerted on the Hungarian banking system during the crisis episode of 2008-2013 if the IFRS 9 standard based on expected credit loss had been introduced before that. The simple simulation model prepared for this showed that, in line with the findings in the literature, the recognition of the Hungarian banking system's losses during the crisis would have been much more front-loaded and occurred in 2008 or 2009 if IFRS 9 had been applied. In parallel with this, banks' capital adequacy would have sustained a major shock of over 20 per cent ( -2.7 percentage points) at the end of 2008, the eve of the crisis. To restore this, bank owners would have been forced to make relatively large capital injections amounting to 2 per cent of Hungarian GDP, or, failing that, compel their banks to press ahead with even more deleveraging. 
Overall, the analysis confirmed the perception that IFRS 9 increased bank impairment relative to the earlier rules, while making the dynamics of impairments more procyclical. In reality and in this simulation as well, this is because under IFRS 9 the impairment of Stage 1 and Stage 2 transactions has to be aligned with the current state of the economy (point-in-time correction), and the transactions with an increased risk since recognition that are nevertheless performing are to be classified as Stage 2; all of this front-loads the recognition of losses at the onset of a crisis. Meanwhile, the standard does not provide banks a proper opportunity to offset this by establishing more impairments in the 'good times' to prepare for a crisis.

It also has to be underlined that although the reduction in capital resulting from the simulation seems to be very large, it tends to suggest that the procyclical effects of IFRS 9 are manageable. First, the 2008-2013 Hungarian crisis episode was extreme by any standard, compounded by a balance of payments crisis, a sovereign debt crisis and an FX debt crisis. Under 'normal' recession circumstances, the procyclical effect of the standard may also be more subdued. Second, the instruments of macroprudential supervisors have expanded considerably since 2008, with the addition of tools (countercyclical capital buffer, capital conservation buffer) which - if used wisely - may have been able to neutralise the major procyclical effects seen in the simulation. However, it must also be added that the primary objective of introducing these instruments was to offset banks' inherent procyclical behaviour, rather than to neutralise the procyclical accounting effects that did not exist before IFRS 9. This increased the complexity of the aspects to be taken into account by supervisors.

Therefore, in the future, supervisors need to pay more attention to managing the procyclical effects arising from banks' recognition of losses, and signs of this can already be seen in the current crisis related to Covid-19.

\section{References}

Abad, J. - Suarez, J. (2017): Assessing the cyclical implications of IFRS 9 - a recursive model. ESRB Occasional Paper Series No 12, European Systemic Risk Board, July. https://www. esrb.europa.eu/pub/pdf/occasional/20170717_occasional_paper_12.en.pdf

Balás, T. (2009): Comparison of the indicators describing the loan portfolio quality of the banking sector. Report on Financial Stability, Update, Background Study III, Magyar Nemzeti Bank. https://www.mnb.hu/letoltes/stabjel-3-balas-200911-en.pdf 
Bíró, G. - Horváth, D. (2020): Újabb lépés segíti az államadósság hátralévő futamidejének növelését (Another step towards extending the residual maturity of government debt). Szakmai cikk (Article), Magyar Nemzeti Bank. https://www.mnb.hu/letoltes/biro-gabriellahorvath-daniel-ujabb-lepes-segiti-az-allamadossag-hatralevo-futamidejenek-noveleset.pdf. Download date: 16 December 2020.

Boer, M. - Gringel, S. (2020): Modeling ECL during the COVID-19 pandemic: Providing flexibility to avoid procyclicality. Institute of International Finance, April. https://www. iif.com/Portals/0/Files/content/Regulatory/04_07_2020_impact_ecl_modeling.pdf. Download date: 16 December 2020.

Borio, C. (2018): New loan provisioning standards and procyclicality. BIS speech, 24 October. https://www.bis.org/speeches/sp181024.htm. Download date: 16 December 2020.

Csekei, E. - Inzelt, Gy. - Szakál, Gy. (2018): Nagy átállás a magyar bankoknál: mit hozott az új számviteli rendszer? (Hungarian banks in transition: what changes has the new accounting system introduced?) Portolio.hu, 5 July. https://www.portfolio.hu/bank/20180705/nagyatallas-a-magyar-bankoknal-mit-hozott-az-uj-szamviteli-rendszer-290968. Download date: 16 December 2020.

EBA (2020): Guidelines on legislative and non-legislative moratoria on loan repayments applied in the light of the COVID-19 crisis. EBA/GL/2020/15, consolidated amended version issued, Consolidated version updated on 2 December. https://www.eba.europa. eu/sites/default/documents/files/document_library/Publications/Guidelines/2020/ GL\%20amending\%20EBA-GL-2020-02\%20on\%20payment\%20moratoria/960349/Final\%20 report\%20on\%20EBA-GL-2020-02\%20Guidelines\%20on\%20payment\%20moratoria\%20 -\%20consolidated\%20version.pdf

ECB (2020): Identification and measurement of credit risk in the context of the coronavirus (COVID-19) pandemic. Letter to the 'To the CEO of the significant institution', SSM2020-0744, Frankfurt am Main, 4 December. https://www.bankingsupervision.europa. eu/press/letterstobanks/shared/pdf/2020/ssm.2020_letter_credit_risk_identification_ measurement $\sim 34 f 2 a 0 b 84$.en.pdf

ESRB (2019): The cyclical behaviour of the ECL model in IFRS 9. European Systemic Risk Board, March. https://www.esrb.europa.eu/pub/pdf/reports/esrb.report190318_reportonthecyclicalbehaviouroftheECLmodel 2347 c3b8da.en.pdf?5c889599e33525ff8da981347ea84ce3

Gaffney, E. - McCann, F. (2019): The cyclicality in SICR: mortgage modelling under IFRS 9. Working Paper Series No 92, European Systemic Risk Board, May. https://www.esrb. europa.eu/pub/pdf/wp/esrb.wp92 bf769a68b8.en.pdf 
Háda, A. (2019): Banking Supervisors Tracing the Transition to IFRS 9. Financial and Economic Review, 18(4): pp. 77-111. http://doi.org/10.33893/FER.18.4.77111

Huizinga, H. - Laeven, L. (2019): The procyclicality of banking: evidence from the euro area. ECB Working Papers No 2288, European Central Bank, June. https://www.ecb.europa.eu/ pub/pdf/scpwps/ecb.wp2288 e0622ceb43.en.pdf

Plata Garcia, C.T. - Rocamora, M. - Rubio, A. - Villar Burke, J. (2017): IFRS 9: Pro-cyclicality of provisions. Spanish banks as an illustration. BBVA Research, Madrid, October. https:// www.bbvaresearch.com/wp-content/uploads/2017/10/2017-10-IFRS-9-Pro-cyclicality-ofprovisions-in-Spanish-banks-1.pdf 